\title{
THE STUDENTS' NEEDS IN DEVELOPING EFL MATERIALS ICT BASED
}

\author{
Muthmainnah $^{1}$, Nur Aeni ${ }^{2}$, Mohammed Galal ${ }^{3}$, K. J. Varghese ${ }^{4}$, Fides Del Castillo ${ }^{5}$, Abd. \\ Ghofur ${ }^{6, *}$ \\ ${ }^{1}$ Teacher Training and Education Faculty, Universitas Al Asyariah Mandar, Polewali Mandar Regency, West \\ Sulawesi 91311, Indonesia \\ ${ }^{2}$ English Language Education Study Program, Faculty of Language and Literature, Universitas Negeri \\ Makassar, South Sulawesi 90221, Indonesia \\ ${ }^{3}$ Ministry of Education and Higher Education Qatar, Doha, Qatar \\ ${ }^{4}$ Christ College Irinjalakuda, Kerala 680125, India \\ ${ }^{5}$ Theology and Religious Education Department, De La Salle University, Taft Ave, Malate, Manila, 1004 \\ Metro Manila, Philippines \\ ${ }^{6}$ English Teaching Learning Program, Tarbiyah Faculty, IAIN Madura, Pamekasan 69371, Indonesia
}

\section{ARTICLE INFO}

Keywords:

Students' need

ELT materials

ICT

Article History:

Received: 22/05/2021

Accepted: 29/11/2021

Available Online:

$30 / 11 / 2021$

\begin{abstract}
A B S T R A C T
In developing English communication skills, the student's needs, wants, and lacks are crucial. The materials given should be suitable for the students' wants. These issues are vital in developing any English materials on ICTbased. This study explores the students' needs, wants, and lacks in learning English by developing suitable materials with the ICT-based. The mixed approach was used in this study. The researchers distributed the survey to 350 students from Indonesia and other countries (Kosovo, Kuwait, Ghana, Pakistan, Philippines, India, and United Kingdom) involved in the Share to Care Community in collecting the data. They were assigned to fill the Google form about their needs in learning English. The result showed that the students need materials that fulfill their needs. It should be related to today's facts, easy enough to share with, and easy to access by the students' technologies devices, then using both target languages L2 and L1 to deliver the materials. While teaching, the lecturers used any method; role-playing is the most common, followed by oral reports, games, outdoor learning, and blended learning. Most of the students from several countries intended to have ICT in their learning process.
\end{abstract}

2442-305X / (C) 2021 The Authors, this is open access article under the (CC-BY-NC) license (https://creativecommons.org/licenses/by-nc/4.0/), DOI: 10.19105/ojbs.v15i2.4679

\footnotetext{
$\bar{*}$ Corresponding Author:

Email address: abd.ghofur@iainmadura.ac.id (A. Ghofur)
}

\section{A. Introduction}

Since early 2020, the learning process has unplanned shifted from conventional to digital because of phenomena the increasingly high utilization of technology in society. A teacher has a very strategic role in the process of learning. The strategic role of 
the teacher in the learning process has an impact on the competencies achieved by students (knowledge, attitudes, skills). ${ }^{1}$ Student competencies will develop optimally depending on how the teacher positions himself and places students' positions in learning. In line with the development of science, there is a paradigm shift where the learning process must be oriented towards active learning students. Teachers must provide opportunities for students to explore when learning.

Educational technology can be regarded as a product and a process. Educational technology is easily considered a product since it is more concrete, such as radio, television, projector, OHP (Overhead Projector), and others. $^{2}$ Meanwhile, as a process, educational technology is considered abstract. In this case, educational technology is understood as a complex and integrated process involving people, procedures, ideas, tools, and organizations to analyze problems and find ways to solve, implement, assess, and manage problems involving all aspects of human life learning.

Entering the era of 4.0 education requires each individual to prepare reliable resources, especially in science and technology. To master technology

\footnotetext{
${ }^{1}$ Abd. Ghofur, "Creative Teaching," OKARA: Jurnal Bahasa dan Sastra 6, no. 2 (2012): 215-20, https://doi.org/10.19105/ojbs.v6i2.430.

2 Judith Parker, "Technology as Integral to a New Paradigm of Adult Education," International Journal of Adult Education and Technology 12, no. 4 (2021): $37-46$,
}

properly, adequate knowledge is needed so that we can use it in facing the demands of the global world, which are conditions with the competition. There have been advances in information and communication technology (ICT) which are growing very rapidly. The use of ICT has been implemented from the levels of primary, secondary, to tertiary education.

In the world of education, especially learning, the development of information and communication technology began to have a positive impact because with the development of information and communication technology, the world of education began to show significant changes. Educational institutions should immediately introduce and start using information and communication technology as a more up-to-date learning base. $^{3}$ This is important, considering the use of ICT is one of the essential factors that allow the speed of the transformation of knowledge to students, the generation of this nation at large.

Analyzing needs is a crucial activity in designing the teaching and learning process. This is in accordance with the design objectives to fulfill student learning needs and teacher teaching needs whose interactions are manifested in the learning

\footnotetext{
${ }^{3}$ Mathew Joseph, Eileen Wall Mullen, and Deborah Spake, "University Branding: Understanding Students' Choice of an Educational Institution," Journal of Brand Management 20, no. 1 (2012): 112, https://doi.org/10.1057/bm.2012.13; José Ramón Calvo-Ferrer, "Educational Games as Stand-Alone Learning Tools and Their Motivational Effect on L2 Vocabulary Acquisition and Perceived Learning Gains," British Journal of Educational Technology 48, no. 2 (2017): 264-78, https://doi.org/10.1111/bjet.12387.
} 
process. Needs assessment is an integral cycle with program development, implementation, and evaluation. ${ }^{4}$ Designing a teaching and learning process that begins with students' needs allowed the results to be optimally utilized by individuals who need them related to ICT-based learning.

\section{A. Need Assessment}

The 'needs' are defined depending on the perception of those making the judgment. The gap between what learners can presently do and what they should do with the language cannot be viewed solely from one perspective. Because it forms a logical basis for all the other components of a formal language curriculum, need Analysis (NA) is necessary for designing a course. ${ }^{5}$ Daugherty backs this up, stating that a need review is an essential first step in developing a curriculum. ${ }^{6}$ Furthermore, he mentioned that need analysis is the systematic gathering and evaluation of all.

Stufflebeam defines needs assessment as a discrepancy or gap. ${ }^{7}$

\footnotetext{
${ }^{4}$ Andi Asrifan et al., "ESP Course Design: The Need Analysis on Tourism Department in Indonesia Vocational High School," Journal of Advanced English Studies 3, no. 2 (2020): 69-77, https://doi.org/10.47354/jaes.v3i2.85.

${ }^{5}$ Sri Diana and Musdalifah Mansur, "Need Analysis on English Teaching Materials for ICT Students," ETERNAL (English, Teaching, Learning, and Research Journal) 4, no. 2 (2018): 209, https://doi.org/10.24252/Eternal.V42.2018.A6.

6 Richard Daugherty, National Curriculum Assessment: A Review of Policy 1987-1994 (London: Routledge, 2004),

7 Daniel L. Stufflebeam and Anthony J. Shinkfield, "Stufflebeam's Improvement-Oriented Evaluation," in Systematic Evaluation: A Self-Instructional Guide to Theory and Practice, ed. Daniel L. Stufflebeam
}

More fully, the needs assessment is defined as the gap between the ideal or supposed conditions and observations in the field. Unsuitable conditions that occur in the field are regarded as a major problem that needs to be addressed. Following the expression of Stufflebeam, namely: the first approach identified is the discrepancy view, a need is a discrepancy or gap between measures or perceptions of desired performance and observed or actual performance, and here in lies a major potential problem. ${ }^{8}$

As an evaluation of most programs, needs analysis focuses on what will be or what should be done, rather than what was done. This statement is in accordance with the implementation of the assessment, namely: Needs assessments are used to address most areas of educational programming. It is intended to assist the practitioner in identifying and managing the many factors impinge on educational decision-making and program improvement. $^{9}$

Needs assessment, in general, is a program evaluation process for program improvement. ${ }^{10} \mathrm{~A}$ needs assessment is a method for identifying and evaluating both values and information. It gives guidance for making program and resource decisions. It could be used in community relations, facilities, planning and

and Anthony J. Shinkfield, Evaluation in Education and Human Services (Dordrecht: Springer Netherlands, 1985), 151-207, https://doi.org/10.1007/978-94-009-5656-8_6.

8 Daniel L. Stufflebeam and Chris L. S. Coryn, Evaluation Theory, Models, and Applications, vol. 50 (New Jersey: John Wiley \& Sons, 2014), 5.

${ }^{9}$ Stufflebeam and Coryn, 50:3.

${ }^{10}$ Stufflebeam and Coryn, 50:3. 
consolidation, program development and assessment, and resource allocation, among other things.

Based on the above definition of needs assessment, a needs assessment is carried out in the following four phases:

1. Identifying and prioritizing objectives to be achieved by answering the questions what should be;

2. Determine the conditions and objectives related to what is the question (what is);

3. Identifying needs which are differences (discrepancy) between expectations to be achieved and existing conditions;

4. Prioritizing the most urgent needs, feasible and feasible to do.

\section{B. ICT in Teaching and Learning Process}

The two aspects of information and communication technology are information technology and communication technology. All aspects of information technology are covered, including the process, tool use, manipulation, and data management. At the same time, communication technology is everything related to tools to process and transfer data from one device to another. In brief, Information and communication technology is the study of the use of electronic equipment, especially computers, to store, analyze, and distribute information, including words, numbers, and pictures. ${ }^{11}$

11 Evizal Abdul Kadir, Apri Siswanto, and Abdul Syukur, "Performance Analysis of Wireless LAN 802.11n Standard for E-Learning," in 2016 4th International Conference on Information and
Included in this technology are:

a. Computer technology, both hardware, and software. It includes processors (data processing), data/information storage media (hard disks, CDs, DVDs, flash disks, memory, memory cards, others), recording devices (CD Writer, DVD Writer), input devices (keyboard, mouse), scanners, cameras, others), and output devices (monitor screens, printers, LCD projectors, speakers, others);

b. Multimedia technology, such as digital cameras, video cameras, sound players, video players, others;

c. Telecommunication technology, telephone, cellular telephone, facsimile;

d. Computer network technology, both hardware (LAN, Internet, Wi-Fi, and others), or software.

Some previous studies conducted need analyses to determine what students need to learn English, which revealed that students need oral presentations, specialized vocabulary lessons, and topics related to their area of specialization. $^{12}$ English skills are required and are necessary the emergency needs, and English communication skills are determined by the English training program. ${ }^{13}$ In any

Communication Technology (IColCT), 2016, 1-6, https://doi.org/10.1109/ICoICT.2016.7571948.

12 Irina Elgort, "Teaching/Developing Vocabulary Using ICTs and Digital Resources," ed. John I. Liontas and Margo DelliCarpini (New Jersey: John Wiley \& Sons Inc., 2018), 3197-3211, https://doi.org/10.1002/9781118784235.eelt0735.

13 Ratmo and Tutut Sumartini, "Needs Analysis of Medical Personnel's English Communication Skills," Lexeme: Journal of Linguistics and Applied 
purpose of English that is given to students' special needs with their understanding to comprehend the materials.

Aeni stated that A critical understanding of English for specific purposes (ESP) requires an in-depth analysis of the particular purpose. Because ESP is related to language use, needs analysis plays a crucial role in designing the ESP program, and designing its materials for teaching. ${ }^{14}$ Designing the materials that are suitable for the student's needs will help them minimize students' lack by delivering all the materials such in this situation on the pandemic; it could be maximizing the use of ICT. Knowing also the competence of the lecturers in using the ICT could improve their easiness in giving the materials.

The factors such as lack of necessary ICT skills and resources to access the course; have greatly impacted their learning. They should join university having good working skills of ICT and good communication skills in English. The university should train them about Elearning tools before they start learning

Linguistics 2, no. 2 (2020): 106-12, https://doi.org/10.32493/ljlal.v2i2.9510; Kyung Hye Kim, "Examining US News Media Discourses about North Korea: A Corpus-Based Critical Discourse Analysis," Discourse \& Society 25, no. 2 (2014): 221-44; Antoon Cox and Shuangyu Li, "The Medical Consultation Through the Lenses of Language and Social Interaction Theory," Advances in Health Sciences Education 25, no. 1 (2020): 241-57, https://doi.org/10.1007/s10459018-09873-2.

${ }^{14}$ Nur Aeni et al., "The Students' Needs in Maritime English Class at Ami Aipi Makassar, Indonesia," Journal of Language Teaching and Research 9, no. $6 \quad$ (2018): 1284 , https://doi.org/10.17507/jltr.0906.18. other subjects. Should they also be equipped with the necessary functional and modern ICT resources to cope with challenges they face in E-learning during pandemics whatsoever. ${ }^{15}$

The results of a need review can be used to help set teaching goals, choose textbooks and teaching methods, and guide course designers in creating English materials. ${ }^{16}$ Another study by Araminta and Halimi performed a need study to determine the English language needs of undergraduate engineering students at an Indonesian university, and the results revealed that the student's English language needs were insignificant. According to the findings of their study, the institution should cooperate with businesses to collect data on language use in the workplace. ${ }^{17}$

The important thing to do in this research that makes it differ from the previous studies was digging on what actually done by the teacher is based on the students need, in this case, some analysis done by the teacher to know

15 Gabriel Bazimaziki, "Challenges in Using ICT Gadgets to Cope with Effects of COVID-19 on Education: A Short Survey of Online Teaching Literature in English," Journal of Humanities and Education Development 2, no. 4 (2020): 299-307, https://doi.org/10.22161/jhed.2.4.8.

${ }^{16}$ Gwo-Jen Hwang, Sheng-Yuan Wang, and ChiuLin Lai, "Effects of a Social Regulation-Based Online Learning Framework on Students' Learning Achievements and Behaviors in Mathematics," Computers \& Education 160 (2021): 104031, https://doi.org/10.1016/j.compedu.2020.104031.

${ }^{17}$ Lavinia DW Araminta and Sisilia Setiawati Halimi, "ASEAN Economic Community 2015: Needs Analysis of Universitas Indonesia's Engineering Students," Indonesian Journal of Applied Linguistics 5, no. 1 (2015): $11-18$, https://doi.org/10.17509/ijal.v5i1.841. 
what is actually needed by the student in some countries in learning English in this digital era. To think outside the classroom, students should also be encouraged to think in educational settings as English as a foreign language (EFL) lessons, not just through subjects like art, music, science, and literature. $^{18}$ Lecturers in some countries definitely play the most important part in promoting students' critical thinking skills through creative teaching.

Based on the phenomenon above, this study's objectives aim to explore the students' needs, wants, and lacks in learning English with developing materials suitable to the students' needs based on ICT.

18 Ismail Xodabande, 'Iranian EFL Learners' Preferences of Different Digital Technologies for Language Learning Beyond the Classroom," International Journal of Education and Literacy Studies 6, no. 3 (2018): 20-31, https://doi.org/10.7575/aiac.ijels.v.6n.3p.20; Seçil Tümen Akyıldız and Vildan Çelik, "Thinking Outside the Box: Turkish EFL Teachers' Perceptions of Creativity," Thinking Skills and Creativity 36 (2020): 1-14, $\quad$ https://doi.org/10.1016/j.tsc.2020.100649; Lori Xingzhen Gao and Lawrence Jun Zhang, "Teacher Learning in Difficult Times: Examining Foreign Language Teachers' Cognitions About Online Teaching to Tide Over COVID-19," Frontiers in Psychology 11 (2020): 549653, https://doi.org/10.3389/fpsyg.2020.549653; CalvoFerrer, "Educational Games as Stand-Alone Learning Tools and Their Motivational Effect on L2 Vocabulary Acquisition and Perceived Learning Gains"; Syariful Imam Hadi Cahyono, Nur Arifah Drajati, and Ngadiso Ngadiso, "Am I a Technophile? The Narrative Study of Teachers' Belief about Digital Literacy," Lingua Didaktika: Jurnal Bahasa dan Pembelajaran Bahasa 14, no. 1 (2020):

$1-11$ https://doi.org/10.24036/ld.v14i1.106724; Marco Cancino and Jaime Panes, "The Impact of Google Translate on L2 Writing Quality Measures: Evidence from Chilean EFL High School Learners," System $98 \quad$ (2021): 102464 , https://doi.org/10.1016/j.system.2021.102464.

\section{B. Method}

This study utilized mix method (quantitative and qualitative approach). The researchers distributed the questionnaire by google form. The researchers distributed the survey to 350 students from Indonesia and other countries involved in the Share to Care Community. They are from Kosovo, Kuwait, Ghana, Pakistan, the Philippines, India, UK. They were assigned to fill the google form about their needs in learning English. In addition, this study involved two lecturers as the respondents to get the additional data to support the survey.

\section{Results}

\section{a. Students' Personal Information}

The research participants were selected from several countries which are involved in the Share to Care Community. Half of the students are in their eighties, ten are in their nineties, and five are in their twenties. Students were questioned about their motivation for studying English. Twenty students (67\%) study English for academic purposes, seven students (23\%) study English for professional purposes, and three students (10\%) study English to interact with others. ICT students are taught by both Indonesian and foreign lecturers; however, the foreign lecturers' language teaching is in English, and the majority of the subject handbooks are written in English. This may explain why they give this option such a high rating. The majority of students begin learning English in elementary school (87\%) and three of them begin learning English in 
junior high school (13\%). They are from different countries which are involved as a member of the Share to Care Community.

\section{b. The Needs of Students to Learn English}

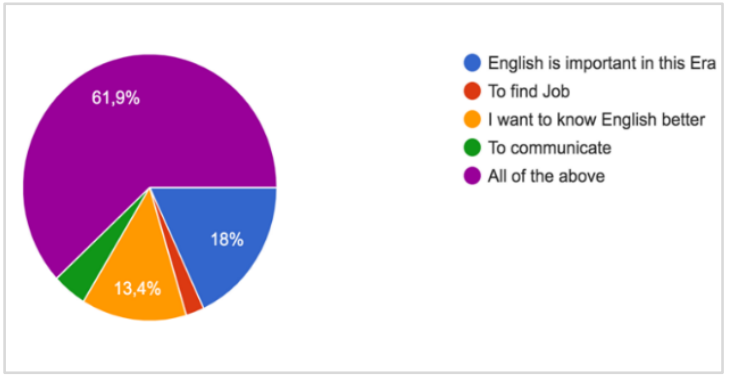

Fig. 1. The importance of English

Based on figure 1, most of the students agree that English is important in this era. $18 \%$ of respondents say so. $13,4 \%$ of respondents state that they want to know English better, and the remaining voters choose that English is important to finding a job and communicating.

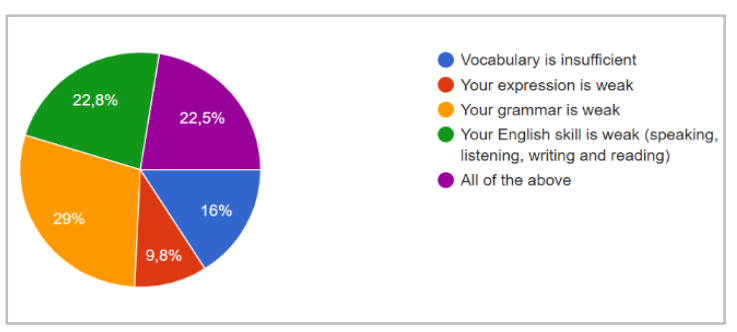

Fig. 2. Students' difficulties in learning English

Figure 2 above shows that the difficulties of the students are so complex, it's shown by $22.8 \%$ of the students lack speaking, listening, writing and also reading skills, $29 \%$ of them show that they were weak in the grammar of English, $22.5 \%$ the students lack on several skills as mention in the figure above. It has been demonstrated that the students need some treatment in learning English.

\section{Language skill needed by Students}

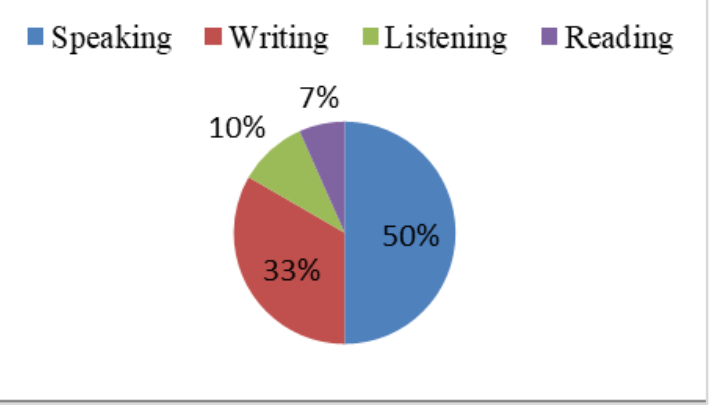

Fig. 3. Language skills needed by the Students

Figure 3 shows that speaking is very important to them. In this 4.0 to 5.0 era, students worldwide believe that oral communication skill has a crucial role in having additional competence and ability to get the best position in the workplace.

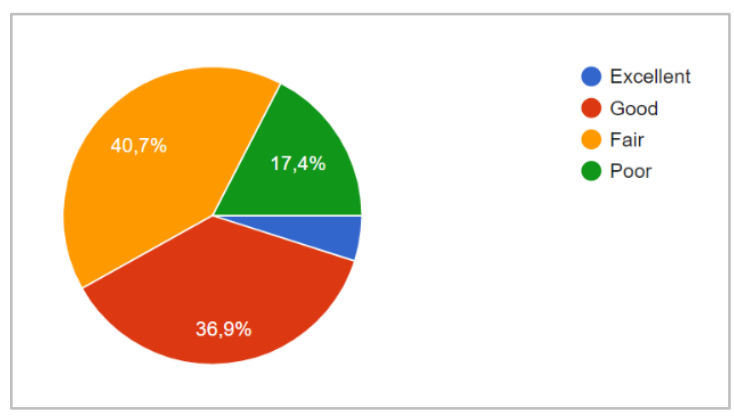

Fig. 4. The Current level of students' speaking and listening skill

While the condition is shown by figure 4 above shows that $40.7 \%$ of students have a fair competence in speaking, while others $17 \%$ are poor in this skill, and only $36 \%$ are good in this skill. It shows us that the student competence in speaking skills is under half of the total number of students in the class. 


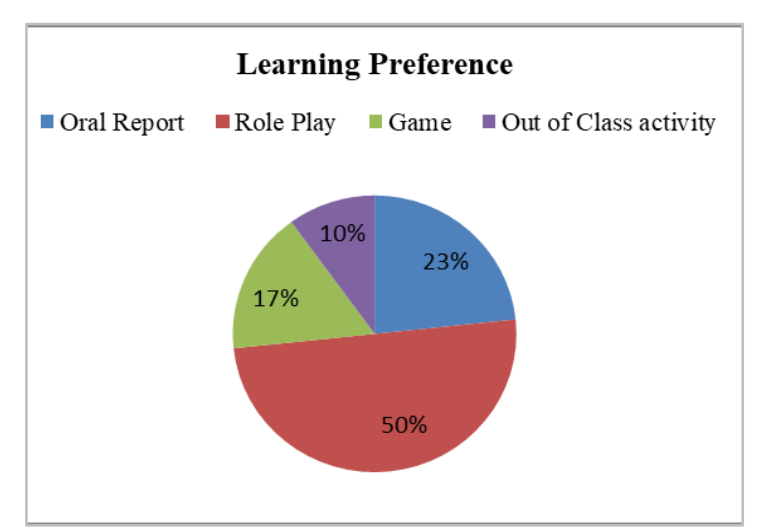

Fig. 5. Learning Preferences by the students

The students were also assigned their preferred method of learning. It is seen in figure 5 above revealed that 175 students $(50 \%)$ selected role-play, 82 students $(23 \%)$ selected oral study, 62 students $(17 \%)$ selected game, and other students $(10 \%)$ selected learn outside of class. Figure 5 shows that students tend to practice their English using the roleplay approach and an oral report. The game is also needed to keep the classroom from being monotonous. This knowledge is important for lecturers to include in English Teaching Materials as course designers.

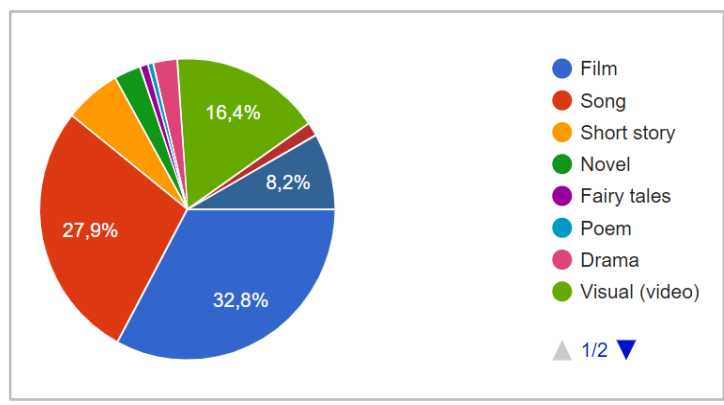

Fig. 6. Learning Preferences by using media

Figure 6 showed that most of the respondents $(32.8 \%)$ liked learning English by using film. They stated that using film in learning English can attract their enthusiasm in learning English. In addition, $27.9 \%$ selected songs as the favorite tools in learning English, $16.4 \%$ chose visual (video) to be a part in learning English, and there were $8.2 \%$ like poem to be inserted in their learning.

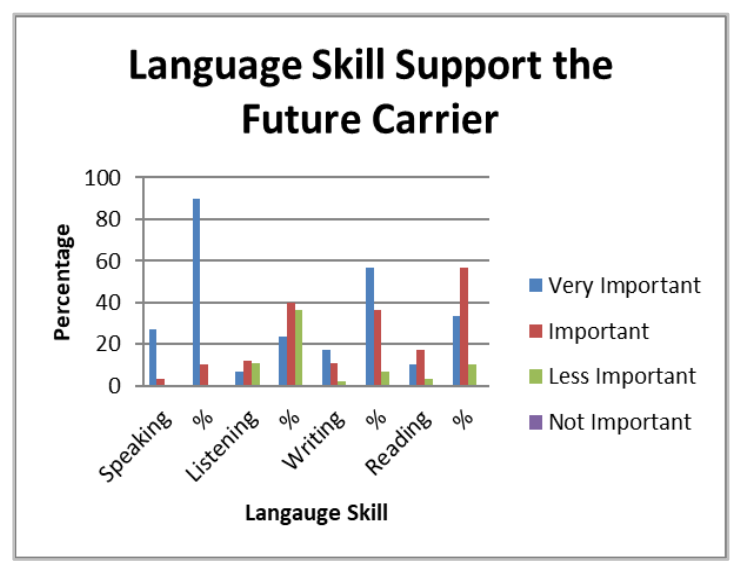

Fig. 7. Language Skills needed for future carrier

The majority of students agreed that using productive skills would be necessary for their future careers. In the case of students, speaking is the most important skill in English, but it is also the most difficult. Speaking received the highest score out of the four language skills, while reading was ranked as the most difficult. The majority of students (90 percent) had trouble speaking and reading (53 percent). In the other case, students are mostly required to speak, but they are also required to write.

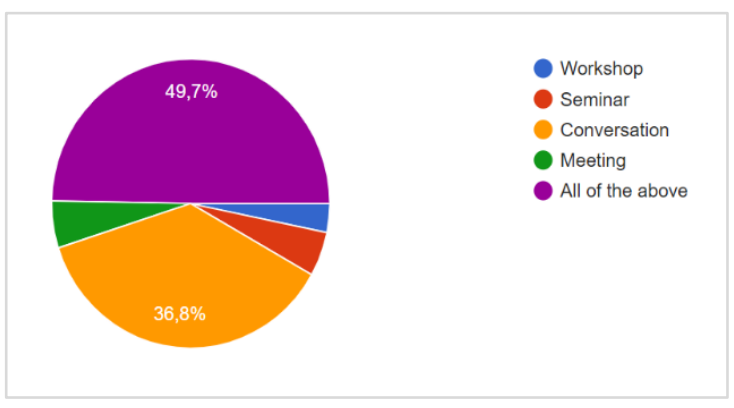

Fig. 8. The context that English is used 
It explained that there were $49.7 \%$ used English for workshops, seminars, conversations, and meetings. They indicated that English is a really crucial part of their daily activities.

\section{c. Students' Perspectives on the Needs of English Language Learning Process}

English lecturers used PowerPoint to illustrate the content, and after the lesson, the lecturers allowed the students to copy the file. In addition to their academic needs, all of the students (100\%) reported that they would be highly interested in taking a specific English course focusing on ICT. While teaching $E F L$, the lectures mix the language used with their own mother tongue, as the student asks their lecturer to make clear their materials catching. This process of learning done by the lecturers shown that the lecturers' competence in delivering the materials by using ICT is highly demanded by the students, as also stated by Bazimaziki, that actually the student and the lecturers lacks in using ICT for recent days learning going to give high impact on the process of teaching, mostly in 4.0 era, that all the technology is going to use in all aspect of life. ${ }^{19}$

\footnotetext{
${ }^{19}$ Bazimaziki, "Challenges in Using ICT Gadgets to Cope with Effects of COVID-19 on Education"; Godwell Nhamo, Charles Nhemachena, and Senia Nhamo, "Using ICT Indicators to Measure Readiness of Countries to Implement Industry 4.0 and the SDGs," Environmental Economics and Policy Studies 22, no. 2 (2020): 315-37, https://doi.org/10.1007/s10018-019-00259-1;

Dragan Peraković, Marko Periša, and Petra Zorić, "Challenges and Issues of ICT in Industry 4.0," in Advances in Design, Simulation and Manufacturing II, ed. Vitalii Ivanov et al., Lecture Notes in
}

Most students stated that learning English need to be more enjoyable. They did not like learning English with only got the assignment without any great activities. 98\% did not enjoy the lesson with reading and reviewing the printed book. $84 \%$ indicated that only a few lecturers inserted social media and ICT into teaching and learning. This finding relates to the study that showed the joyful learning on the use of ICT in learning. ${ }^{20}$

This study included two lecturers as participants in each of the countries as the setting of the study. They're both from the English educational school. They have been teaching English at this institution for over two years. The researcher discovered that during the interview that the majority of the materials were not adapted to the English learning needs of the students at this institution. During an interview with two English lecturers, they indicated that students must master their vocabulary to develop their language skills, especially speaking and writing.

Lucas, a lecturer from the UK, states that:

"...blended flipped teaching was used during the teaching process. Knowledge is effectively conveyed through micro-course films, other learning materials, and class-teaching activities based on real-world issues.

\begin{tabular}{|c|c|c|}
\hline $\begin{array}{l}\text { lechanical } \\
\text { ternational } \\
\text { ttps://doi.org/ } \\
\text { Joanna Le€ }\end{array}$ & $\begin{array}{l}\text { Engineering (Cham: } \\
\text { Publishing, 2020), } \\
\text { 10.1007/978-3-030-22365-6 } \\
\text { and Marcin Rojek, "ICT } \\
\text { n Social Polarization and S } \\
\text { nal Learning: Cases of Y } \\
\text { s," Interactive Learning Env }\end{array}$ & $\begin{array}{l}\text { Springer } \\
259-69 \text {, } \\
26 .\end{array}$ \\
\hline
\end{tabular}


Off-the-clock learning was organized and deliberate. When ICT-based language teaching materials are employed in the classroom, they will help students learn and retain information."

ICT is also utilized in the off-class time to push the learning content actively and maximize the success of mobile learning. It was possible to create a continuous blended spatial system with intelligent, tailored, diverse mobile learning and management by expanding standard classroom learning to an "offclass autonomous inquiry learning + class information absorption + after school knowledge push" model.

International efforts and resources have been given to integrating and promoting ICT for foreign language teaching and learning. It has been found that the employment of modern digital technology in education has not yet been firmly established in the teaching methods at Philippine, Kosovo, Kuwait, Pakistan, India, Ghana, United Kingdom, and Indonesia universities, according to lecturers.

Another informant, Elngar stated that:

"...For the most part of Kuwait universities aren't taking the lead in supporting their language teaching personnel and students in the use of ICT in a significant way."

ICT as a teaching tool is outlined in this study. In other words, higher education in Asia is still fighting to receive enough ICT infrastructure and electronic or mobile devices to facilitate this study.
Teachers in Asia are reluctant to adapt their teaching methods to accommodate these new digital literacies, even if many of their students are adept at using them. Until recently, foreign language teachers in Western and Euro countries relied primarily on the written word; today, they have access to video clips, official documents, PowerPoint presentations, and online libraries from around the world. The most essential component for foreign language teachers is to use the numerous opportunities that ICTs present for the teaching and study of foreign languages. Research has shown that ICTs can be an effective tool in broadening educational attainment. Still, most language teachers at universities in this study do not use these technologies regularly as an instructional delivery system, even though they have access to a limited amount of digital material.

All the lecturers' perceptions related to ICT are used as teaching materials for EFL. Developing teaching materials using ICT is a very interesting strategy to engage students; affective engagement, behavioral engagement, cognitive engagement, and social-cultural engagement. Essentially, lecturers promote the production of EFL teaching materials that incorporate ICT or films by incorporating the YouTube application, which enables students to comprehend the language in its native speaker context, but the big challenge is the ICT infrastructure.

Authorities in the Asian region are placing a high priority on ICT resource development in view of the worldwide shift 
toward a knowledge-based society. Implementation of "technology infrastructures for communication and scientific and technical information," a "distance-learning infrastructure," and a "virtual library" are the major obstacles in Asia country."

Speaking skills are used to connect with their professor, and writing skills are used to complete their paper task. The lecturers emphasized that the institution did not have a permanent syllabus. The instructor creates instructional materials based on their own values and theories rather than the needs of the students. English is extremely important to all lecturers, not just in the classroom but also in their future careers. The materials for the English class should be focused on the students' interests. What happens above really should be solved by the lecturer. By discovering the student's needs is important to ensure the materials given are suitable with the needs of the students and how those materials could be delivered in teaching and learning. ${ }^{21}$

\section{Conclusion}

In consummation, this study indicates that language skills are the most important and urgent for students in their current situation and their future careers. The lecturers used both English and the student's mother to teach English. When it comes to teaching methods, roleplaying is the most common, followed by

21 Tom Hutchinson and Alan Waters, English for Specific Purposes (Cambridge: Cambridge University Press, 1987); Tom Hutchinson and Alan Waters, "How Communicative Is ESP?," ELT Journal 38, no. 2 (1984): 108-13. oral reports, games, and doing some activities outside of the classroom to help students learn English. Most of the students from several countries intended to have ICT in their learning process. In this case, to make the learning materials easy to understand, the lecturers sometimes support the topic with a short film. These materials make the student more interesting in following them.

What has already been done by the researchers, with exploring the study's objective limited only on the country being studied, there are many aspects that other researchers could dig to know more about teaching a language, especially English as a foreign language. In this case, this study could make an important decision for the policymaker to support all aspects of the teaching of English need, both the infrastructure of ICT used by the lecturer, improving teaching method and lecturers competent in choosing any English materials that suitable with the students' needs.

\section{References}

Aeni, Nur, Baso Jabu, Muhammad A. Rahman, Hamid Ismail, and Saidna Z. Bin-Tahir. "The Students' Needs in Maritime English Class at Ami Aipi Makassar, Indonesia." Journal of Language Teaching and Research 9, no. 6 (2018): 1284. https://doi.org/10.17507/jltr.0906.18.

Araminta, Lavinia DW, and Sisilia Setiawati Halimi. "ASEAN Economic Community 2015: Needs Analysis of Universitas Indonesia's Engineering Students." Indonesian Journal of Applied Linguistics 5, no. 1 (2015): 11-18. https://doi.org/10.17509/ijal.v5i1.841. 
Asrifan, Andi, K. J. Vargheese, Syamsu T, and Muhammad Amir. "ESP Course Design: The Need Analysis on Tourism Department in Indonesia Vocational High School." Journal of Advanced English Studies 3, no. 2 (2020):

$69-77$. https://doi.org/10.47354/jaes.v3i2.85.

Bazimaziki, Gabriel. "Challenges in Using ICT Gadgets to Cope with Effects of COVID-19 on Education: A Short Survey of Online Teaching Literature in English." Journal of Humanities and Education Development 2, no. 4 (2020): 299307.

https://doi.org/10.22161/jhed.2.4.8.

Cahyono, Syariful Imam Hadi, Nur Arifah Drajati, and Ngadiso Ngadiso. "Am I a Technophile? The Narrative Study of Teachers' Belief about Digital Literacy." Lingua Didaktika: Jurnal Bahasa dan Pembelajaran Bahasa 14, no. 1 (2020): 1-11. https://doi.org/10.24036/ld.v14i1.106 724.

Calvo-Ferrer, José Ramón. "Educational Games as Stand-Alone Learning Tools and Their Motivational Effect on L2 Vocabulary Acquisition and Perceived Learning Gains." British Journal of Educational Technology 48, no. 2 (2017): 264-78. https://doi.org/10.1111/bjet.12387.

Cancino, Marco, and Jaime Panes. "The Impact of Google Translate on L2 Writing Quality Measures: Evidence from Chilean EFL High School Learners." System 98 (2021): 102464.

https://doi.org/10.1016/j.system.202 1.102464 .

Cox, Antoon, and Shuangyu Li. "The Medical Consultation Through the Lenses of Language and Social Interaction Theory." Advances in Health Sciences Education 25, no. 1 (2020): 241-57. https://doi.org/10.1007/s10459-01809873-2.
Daugherty, Richard. National Curriculum Assessment: A Review of Policy 1987-1994. London: Routledge, 2004.

Diana, Sri, and Musdalifah Mansur. "Need Analysis on English Teaching Materials for ICT Students." ETERNAL (English, Teaching, Learning, and Research Journal) 4, no. 2 (2018): 209-18. https://doi.org/10.24252/Eternal.V42 .2018.A6.

Elgort, Irina. "Teaching/Developing Vocabulary Using ICTs and Digital Resources." edited by John I. Liontas and Margo DelliCarpini, 3197-3211. New Jersey: John Wiley \& Sons Inc., 2018. https://doi.org/10.1002/9781118784 235.eelt0735.

Gao, Lori Xingzhen, and Lawrence Jun Zhang. "Teacher Learning in Difficult Times: Examining Foreign Language Teachers' Cognitions About Online Teaching to Tide Over COVID-19." Frontiers in Psychology $11 \quad$ (2020): 549653. https://doi.org/10.3389/fpsyg.2020.5 49653.

Ghofur, Abd. "Creative Teaching." OKARA: Jurnal Bahasa dan Sastra 6, no. 2 (2012): 215-20. https://doi.org/10.19105/ojbs.v6i2.43 0 .

Hutchinson, Tom, and Alan Waters. English for Specific Purposes. Cambridge university press, 1987.

Hutchinson, Tom, and Alan Waters. "How Communicative Is ESP?" ELT Journal 38, no. 2 (1984): 108-13.

Hwang, Gwo-Jen, Sheng-Yuan Wang, and Chiu-Lin Lai. "Effects of a Social Regulation-Based Online Learning Framework on Students' Learning Achievements and Behaviors in Mathematics." Computers \& Education 160 (2021): 104031. https://doi.org/10.1016/j.compedu.2 020.104031 . 
Joseph, Mathew, Eileen Wall Mullen, and Deborah Spake. "University Branding: Understanding Students' Choice of an Educational Institution." Journal of Brand Management 20, no. 1 (2012): 1-12. https://doi.org/10.1057/bm.2012.13.

Kadir, Evizal Abdul, Apri Siswanto, and Abdul Syukur. "Performance Analysis of Wireless LAN 802.11n Standard for E-Learning." In 2016 4th International Conference on Information and Communication Technology (ICoICT), 1-6, 2016. https://doi.org/10.1109/IColCT.2016. 7571948.

Kim, Kyung Hye. "Examining US News Media Discourses about North Korea: A Corpus-Based Critical Discourse Analysis." Discourse \& Society 25, no. 2 (2014): 221-44.

Leek, Joanna, and Marcin Rojek. "ICT Tools in Breaking Down Social Polarization and Supporting Intergenerational Learning: Cases of Youth and Senior Citizens." Interactive Learning Environments (2021): $1-16$. https://doi.org/10.1080/10494820.20 21.1940214.

Nhamo, Godwell, Charles Nhemachena, and Senia Nhamo. "Using ICT Indicators to Measure Readiness of Countries to Implement Industry 4.0 and the SDGs." Environmental Economics and Policy Studies 22, no. 2 (2020): 315-37. https://doi.org/10.1007/s10018-01900259-1.

Parker, Judith. "Technology as Integral to a New Paradigm of Adult Education:" International Journal of Adult Education and Technology 12, no. 4 (2021): 37-46. https://doi.org/10.4018/IJAET.20211 00103.

Peraković, Dragan, Marko Periša, and Petra Zorić. "Challenges and Issues of ICT in Industry 4.0." In Advances in Design, Simulation and Manufacturing II, edited by Vitalii
Ivanov, Justyna Trojanowska, Jose Machado, Oleksandr Liaposhchenko, Jozef Zajac, Ivan Pavlenko, Milan Edl, and Dragan Perakovic, 259-69. Lecture Notes in Mechanical Engineering. Cham: Springer International Publishing, 2020. https://doi.org/10.1007/978-3030-22365-6_26.

Ratmo, and Tutut Sumartini. "Needs Analysis of Medical Personnel's English Communication Skills." Lexeme: Journal of Linguistics and Applied Linguistics 2, no. 2 (2020): 106-12. https://doi.org/10.32493/jlal.v2i2.95 10.

Stufflebeam, Daniel L., and Chris L. S. Coryn. Evaluation Theory, Models, and Applications. Vol. 50. New Jersey: John Wiley \& Sons, 2014.

Stufflebeam, Daniel L., and Anthony J. Shinkfield. "Stufflebeam's Improvement-Oriented Evaluation." In Systematic Evaluation: A SelfInstructional Guide to Theory and Practice, edited by Daniel L. Stufflebeam and Anthony J. Shinkfield, 151-207. Evaluation in Education and Human Services. Dordrecht: Springer Netherlands, 1985. https://doi.org/10.1007/97894-009-5656-8_6.

Tümen Akyıldız, Seçil, and Vildan Çelik. "Thinking Outside the Box: Turkish EFL Teachers' Perceptions of Creativity." Thinking Skills and Creativity 36 (2020): 1-14. https://doi.org/10.1016/j.tsc.2020.10 0649.

Xodabande, Ismail. "Iranian EFL Learners' Preferences of Different Digital Technologies for Language Learning Beyond the Classroom." International Journal of Education and Literacy Studies 6, no. 3 (2018): 20-31.

https://doi.org/10.7575/aiac.ijels.v.6 n.3p.20. 